\title{
Mediating Role of Psychosocial Factors on the Relationship between Downsizing and Employees' Commitment to Work among Federal Civil Servants in Nigeria
}

\author{
Adeboye Titus Ayinde \\ Department of Psychology, Obafemi Awolowo University, \\ Ile-Ife, Osun State, Nigeria \\ Tel: +234-803-601-9665,+234-802-829-4888＜noBreak>Email: adedickson@yahoo.com
}

Received: June 14, 2011 Accepted: August 9, 2011 doi: 10.5430/jms.v2n3p2

\begin{abstract}
The study assessed the mediating role of psychosocial factors on the relationship between employee's perception of downsizing exercise and their commitment to work in selected public sector establishments in Nigeria.

The study employed descriptive survey design and a Multi- stage sampling technique was adopted. Purposive sampling technique was used to select six Federal Government establishments in Abuja and Lagos State. Using stratified random sampling, a total of 604 respondents comprising (58.9\%) males and (41.1\%) females were selected from these establishments. Data were collected through the administration of standardized psychological tests: General Perception of Downsizing (GPD), Tennessee Self-Concept Scale (TSCS), and Organizational Commitment Questionnaire (OCQ). Data collected were analyzed using appropriate descriptive and inferential statistics.

The results showed a significant positive relationship between employee's perception of downsizing and their work commitment $(\mathrm{r}=0.17 ; \mathrm{p}<0.05)$. That is, employee's perception of downsizing exercise influenced their commitment to work. The results also showed that employees' perception of downsizing was significantly related to psychosocial factors, i.e. Self-Concept $(r=0.25 ; p<0.01)$; and Length of Service $(r=0.11 ; p<0.01)$. Furthermore, the results showed that Self-Concept and Length of service significantly and independently mediated the relationship between employee's perception of downsizing and their commitment to work, $(\beta=0.36 ; \mathrm{t}=9.24 ; \mathrm{p}<0.01)$; and $(\beta=0.14 ; \mathrm{t}=3.56 ; \mathrm{p}<0.01)$ respectively.

The study concluded that employees' perception of downsizing related to their commitment to work. This relationship was, however, mediated by employees' self-concept and length of service.
\end{abstract}

Keywords: Psychosocial, Downsizing, Commitment, Employees, Self Concept, Length of Service

\section{Introduction}

The study of employees' commitment in the aftermath of downsizing exercise becomes important because organizations are required to maintain a core of committed individuals who will sustain life in organizations after a reduction in the work force. Those who remain represent the "heart, brain, and muscle" of the organization (Meyer \& Allen, 1997). Therefore it is very pertinent to know the attributes that should be possessed by those employees who are retained. On the other hand, workers who become less committed to an organization, especially, after the major shakeup, tend to route their experience and envisage what probably lies ahead of them. Consequently, they tend to start to evaluate their skills and experience in terms of their marketability outside of the organization, rather than by the implication for their current or future jobs in the organization. Thus, it is important to know how to develop the right type and level of organizational commitment to ensure that the better employees are those that were retained.

In the period of radical changes such as; mergers, outsourcing, and downsizing, employees may feel that their attachment to the organization has changed, usually decreased. The main reason leading to decreased commitment during these organizational changes is strongly connected to factors such as feelings of job insecurity, decreased trust, job redesign, and increased stress (Dordevic, 2004). Some authors conceptualize job insecurity as the perception of a potential threat to continuity (Greenhalgh and Rosenblatt, 1984). As regards decreased trust, employees may express decreased trust in management when they consider management behaviour as unethical. On job redesign, a significant concern of many employees during the radical changes is their inability to absorb and cope with increased workloads. Radical organizational changes often lead to increased stress, which consequently leads to reduced commitment in organization. It 
is obvious that employees are mindful of all these factors and this has tendency to affect their dispositions in the aftermath of downsizing.

The phenomenon of downsizing has lately become a recurrent issue in the public sector (Lloyds \& Weissman, 2001). The recent global economic events may have made the decision to downsize a veritable choice, most especially among the developing countries of the world. Downsizing, even though, appears as a new terminology within the context of the public sector of Nigeria, but it has all the indications of retrenchment, which is a familiar terrain in the nation's civil service. The spate of mass retrenchment that accorded the civil service reforms of 1975 and 1984 in Nigeria, coupled with cases of staff dismissal that followed minimum wage increment in 1999/2000 can attest to this fact. For instance, States like Osun and Lagos embarked on mass retrenchment exercise, where 15,000 and 12,000 public servants including teachers were dismissed from both states (Socialist Democracy, 2002).

Currently, organizational restructuring/downsizing is the first on the list under operation and system, which is the fourth cardinal point of the public service reforms in Nigeria (Adegoroye, 2006). The other three are; privatizations, liberalization, and restructuring of government spending. The reforms were targeted at improving service delivery and promoting good governance. The fallout of restructuring are the cases of layoffs, which include the over 1,000 staff of the National Bureau of Statistics whose appointment were terminated, and the 1,350 staff of the Ministry of Solid Minerals Development who were relieved of their jobs on $31^{\text {st }}$ December 2005 (Adegoroye, 2006). A host of other Government establishments such as Nigeria Port Authority, (NPA) Lagos, Federal Character Commission (FCC) Abuja etc. have also disengaged substantial number of workers from service, while many are still compiling names of those to be laid off.

Moreover, as the goal of revamping the economy is unfolding in Nigeria, the government downsizing policy and the likely psychological trauma that may accompany the exercise may have begun to take its hold on the people. The retrenched workers, as well as those who were left behind, may have started to witness career destruction as a result of changes in work environments, and job redesign created by downsizing exercise. While the laid-off workers may quickly accept their fate and, to a greater extent, pose no problem to their immediate past organizations, the changes in work environment created by the exercise may affect the retained workers' commitment to work. More so, there is tendency for tremendous loss of energy, talents, and organizational knowledge in the aftermath of downsizing policy. For the individual workers, it might also cause damage to morale, and feelings of job insecurity. Downsizing may induce symptoms such as fear, distrust, and distress in the 'survivors' and these symptoms generate different reactions from them. These experiences, however, are subjective in nature and the reactions generated by them may also depend on individuals' personal and social factors. This study considers the mediating role of psychosocial factors, which include self-concept and length of service on the relationship between employees' perception of downsizing and their commitment to work. It sets out, not only to investigate employees' reactions to organizational change like downsizing, but to determine how these variables influence employees' work behaviours i.e. commitment, in the aftermath of downsizing.

Employees' self concept may influence their commitment to work in the aftermath of organizational change like downsizing. Individual's beliefs and understanding of self may affect the way the changes brought about by downsizing are interpreted and subsequently reacted to. Mishra and Spreitzer (1998) group layoff 'survivors' behaviour into two broad categories: constructive and destructive. "Constructive 'survivors' behaviour includes obliging responses of feeling calm, relief, commitment, expression of hope, excitement, optimism, and willingness to solve problems and take initiatives. Destructive responses are feelings and expressions of fear, anxiety, helplessness, withdrawal and procrastination". It also includes cynicism, anger, disgust, retaliation and the tendency to badmouth the organization. Self-concept has tendency to influence whichever ways employees choose. Employees' personality has been found to be consistent with specific work behaviour after a major organizational change (Guttman, 1973). A considerable volume of researches (Strauser, 1995; Strauser, Waldrop, Hamsley \& Jenkins, 1998; Judge \& Hurst, 2007; Best, Stapleton \& Downney, 2005; Bono \& Colbert, 2005; Salvaggio, Schneider, Nishii, Mayer, Ramesh \& Lyon, 2007) on the role of self-concept in occupational development can attest to the above assertion.

The rationale for including employees' length of service as one of the mediating variables was based on belief that employees with longer years in service have more to lose and, therefore, are presumemably less likely to leave their organizations (Ritzer \& Trice, 1969). O'Reilly and Chatman (1986) contend that employees with longer tenure may have stronger identification with the value and goals of the organization. This invariably means that the longer the length of time in service the more adaptable the employees become. Studies have established commitment to be correlated to length of service, based on the assumption that long stay in an organization would mean higher commitment (Cohen, 1993). Length of service has been found to be consistently related to commitment (Mowday et al, 1982 \& Griffin \& Bateman, 1986). Cohen (1993) examines the correlation between commitment and age on one hand and commitment 
and length of service on the other hand within different career stages. He found that the correlation was greater among the more senior employees, that is, those with more than nine years experience. Ajila and Okeowo (2004) report a significant difference between younger employees and older employees in their commitment to work. This is an indication of consistence relationship between employees' age and their commitment to work. In a related study, Ayinde (2005) found that higher number of years in service is correlated with employees' expression of satisfaction with performance appraisal process. Therefore, an assessment of psychosocial factors and their mediating role on the relationship between employees' perceptions of downsizing on their commitment to work can be used to explain the disparity in levels of employees' reactions to downsizing in the public service.

\subsection{Statement of the Problem}

Evaluation of employees' commitment to work in the aftermath of downsizing becomes important in view of the fact that when downsizing occurs, employees who are laid off as well as those who remain (survivors) could be adversely affected. This should be of concern to organizations, given the fact that those who survived downsizing may have just had their world turned upside down. Consequently, they may experience a change in their commitment to the organization. Bragg (2002) distinguishes between two types of employees commitments in the aftermath of downsizing, i.e. 'want to' commitment and 'have to' commitment. Those employees who want to work for their employers outperformed those who have to work for them (Bragg, 2002). It appears that employees who survived downsizing constitute majority of workers in many of the establishments after restructuring. The implication is that employees who do stay are not necessarily loyal by choice and they are not sometimes committed employees, but employees who are trapped in their jobs. Organizational health depends on the continued commitment of those individuals remaining with the organization after downsizing has occurred (Kaye, 1998). If this group of workers have their morale dampened, it may spell doom for such organization.

Moreover, downsizing in the public service of Nigeria may have dealt a great blow to the morale of an average civil servant who survived the exercise. This may also affect their commitment to work in the long run. Given these conditions, the problem of achieving the objectives (reinvigorating the public service and improving service delivery) with the latest downsizing exercise becomes inevitable. Herscovitch and Meyer (2002) contend that one of the most prevalent factors contributing to failed-restructuring is a lack of commitment by employees. It is envisaged that employees who exhibit high level of commitment tend to be highly satisfied and are fulfilled by their jobs. This will no doubt aid development of proactive and innovative public service organizations. The problem becomes more pronounced in view of the peculiar nature of the public service in Nigeria. Downsizing exercise is likely to pose a special problem in Nigeria in the sense that an average Nigerian civil servant has a different conception of job, unlike their counterparts in corporate environment. A worker in the public service often feels secured, believing that his or her job is tied to retirement and is 'pensionable'. But with the recent government's public service reforms, this may no longer be guaranteed. Thus, negative trend in employees' commitment may ensue.

Furthermore, studies of downsizing have always revolved around three basic themes, which include; effect of downsizing on the financial performance of organizations, effect of downsizing on its 'victims', and its effect on those who remain after it has taken place. Those researchers (Brockner, Grover, Reed, Dewitt, \& O’Malley, 1987; Spreitzer \& Mishra, 2002; Guiniven, 2001; Wanberg, Bunce \& Gavin, 1999) who concentrate on 'survivors' had only analyzed employees perception of downsizing along the single dimension such as perceived fairness in the process or perceived procedural justice of downsizing, and perceived breach of psychological contract, and these have often been in the private sector. Few empirical investigations had analyzed employees' perceptions of downsizing in relation to employees' commitment to work with attendant mediating role of psychosocial factor on such work behaviours in the public sector. While all the factors examined by earlier researchers (Anderson-Connolly \& Greenberg 2000; Turnley \& Feldman 1998; Brockner \& Wiesenfeld 1996; and Brockner, Wiesenfeld \& Martin 1995; Robinson, Kraatz \& Rousseau 1994) on perception of downsizing are more in the private establishments and aimed at determining the acceptability status of downsizing to the employee, the present research efforts represent a movement towards identifying those factors that can aid survivors' adjustment, as reflected in their commitment to work, to changes brought about by downsizing, especially in the public service.

Meanwhile, there are a few recent studies (Lee \& Peccei, 2006; Armstrong-Stassen 2001; Camp \& Steiger 1995) on the relationship between psychosocial variables and specific job behaviour during the organizational change. While much conceptual discussions (Evered, 1977; Kirton \& Mulligan, 1973; Marsteller \& Slocum, 1972) on the personality characteristics of workers on employees' reactions to organizational restructuring had only reflected nearly aging analysis, the present study attempts to improve on the previous works in the area. This study examines the mediating role of psychosocial factors (Self-concept and length of service) on the relationship between perception of downsizing and 
Nigeria workers' commitment to work. The variables are expected to lend credence to predictive factors that go into successful coping mechanisms among workers in the public service of Nigeria in the aftermath of the exercise.

\section{Attribution Theory}

Attribution theory is concerned with how individuals interpret events and how this relates to their thinking and behaviour. Heider's attribution theory considers how the average person constructs the meaning of an event based on his /her motives to find a cause and his/her knowledge of the environment. Thus, the theory basically looks at how people make sense of their world; what cause and effect inferences they make about the behaviours of others and of themselves. Heider states that there is a strong need in individuals to understand transient events by attributing them to the actor's disposition or to stable characteristics of the environment. The purpose behind making attributions is to achieve cognitive control over one's environment by explaining and understanding the causes behind behaviours and environmental occurrences. Making attributions gives order and predictability to our lives; helps us to cope. Heider (1958) was the first to propose a psychological theory of attribution, but Weiner $(1974,1986)$ and colleagues developed a theoretical framework that has become a major research paradigm of social psychology.

Weiner (1974) focused his attribution theory on achievement. He identified ability, effort, task difficulty, and luck as the most important factors affecting attributions for achievement. Attribution theory is closely associated with the concept of motivation. The theory has been used to explain the difference in motivation between high and low achievers. According to attribution theory, high achievers will approach rather than avoid tasks related to succeeding because they believe success is due to high ability and effort which they are confident of. Failure is thought to be caused by bad luck or a poor exam, i.e. not their fault. Thus, failure does not affect their self-esteem but success builds pride and confidence. On the other hand, low achievers avoid success-related chores because they tend to (a) doubt their ability and/or (b) assume success is related to luck or to "who you know" or to other factors beyond their control. Thus, even when successful, it is not as rewarding to the low achiever because he/she doesn't feel responsible, i.e., it does not increase his/her pride and confidence.

\subsection{Implications of Attribution Theory to the Present Study}

The present study focuses on mediating role of psychosocial factors in the relationship between employees' perception of government's downsizing exercise and organizational commitment. Thus, application of attribution theory explains employees' cognitive and behavioural reactions, to organizational changes such as downsizing. The theory implies how the average employee interprets downsizing event based on his/her motive to find cause and to make inferences about the behaviour of others and themselves. This invariably indicates that employee has tendency to attribute a cause of downsizing event to either government or inefficiency on the part of workers. Based on this assumption, the present study proposes that employees who probably attribute the cause of downsizing to government policy tend to have lower organizational commitment, while employees who attribute downsizing to lack of skills and inefficiency on the part of workers (especially those that were laid off) will exhibit higher organizational commitment, even if it is meant to avoid similar treatment.

There is a strong relationship between self-concept and achievement. Weiner (1980) states: "Causal attributions determine affective reactions to success and failure. For example, one is not likely to experience pride in success, or feelings of competence, when escaping lay-off which does not spare people on the basis of merit or performance. On the other hand, an escape from downsizing of workers exercise based on inefficiency or poor performance as a result of outstanding performance generates great positive effect. Employees with higher ratings of self-concept tend to attribute success to internal, stable, uncontrollable factors such as ability, while they attribute failure to either internal, unstable, controllable factors such as effort. For example, employees who see themselves as being competent tend not to be threatened by the recent government's downsizing exercise, but rather resolve to be more committed, believing in his/her ability to escape the subsequent lay-off exercise. On the other hand, employees who see themselves as less competent tend to absorb various symptoms of downsizing like fear and anxiety. Such employees may rely on luck to escape the subsequent lay-off exercise instead hard-work, good performance and job involvement that culminate into organizational commitment.

\subsection{Conceptual Framework}

The conceptual framework on the relationship between downsizing and organizational commitment, and the mediating role of psychosocial factors on the relationship, is expected to explain the focus of the present study. The model, as presented in Figure 1, explains the influential role of downsizing policy of the Federal Government on employees' commitment to work, as well as the mediating role of psychosocial factors, including the self-concept and length of service on this relationship. 


\section{Research Methods}

Descriptive survey is employed in this study. The order of the research variables is as follows; the independent variable is perception of downsizing exercise, the mediating variables are personal characteristic such as self-concept and job characteristic such as length of service, while the dependent variable is employees' commitment to work. The study population consists of civil servants in the Federal Ministries, Parastatals and Agencies. The Federal Civil Service as at the year 2005 (the year preceding the commencement of downsizing exercise), consists of 307,566 staff. The figure is total sum of 145,195 (47\%) workers from the 31 Ministries/Extra-Ministerial Departments and 162,371 (52\%) workers from 158 Federal Parastatals and Agencies (Federal Character Commission, Tenth Annual Report 2005, 2007).

\subsection{Sample Size and Sampling Procedure}

The study adopted a multi-stage sampling technique in the process of the selection and the collection of data. These sampling techniques include; the purposive, stratified and random sampling method. The purposive sampling technique was used in selection of six Federal Government's establishments. These consist of two Ministries (Ministry of Finance and Ministry of Mines and Steels Development), two Parastatals (Nigeria Port Authority and National Council for Museums and Monuments) and two Agencies (National Orientation Agency and Federal Character Commission), all in Abuja and Lagos State. The selection was based on the following criteria: firstly, that the establishments selected belong to the public sector, secondly, the establishments were among the public institutions where downsizing had been carried out. The stratified sampling technique, which specified that the sample be first classified along specific criteria, was also used. The selected establishments were stratified into ministries, parastatals and agencies, from which a total number of 604 participants who responded to the research instrument were selected randomly.

\subsection{Research Instrument}

The research instrument used for the collection of data in this study is divided into three-section comprising scales that are already in use. The first area contains Section 'A', which tapped information on respondents' social demographic variables. The second area contains Section 'B' which measured independent variables, employees' general perception of downsizing. The third aspect contains Sections ' $\mathrm{C}$ ' which measured the dependent variables, employees' commitment to work (organizational commitment). It has fifty items including those of demographic data. The three sections of the questionnaire and their pre-occupation are presented below:

\section{Section A: Demographic Data}

This section contains seven-item, which sought information on respondents' demographic characteristics. These include, age, sex, marital status, education, job position/status, and length of service. It is important to collect information on such variables in order to gain a better understanding of how they contribute to employees' perception of downsizing and their levels of commitment to work.

Age has no specific range or categories; respondents are to write their age. Although most feasible age to join the Federal Civil Service in Nigeria for non-graduate is 18 years, while 25 years is adopted as the optimal age for basic degree graduate entry (BPSR, 2006). Sex variable has two options; male or female. Marital status also has four categories; single, married, divorce, and others. Education has no specific category; respondents were asked to indicate their educational qualifications. However, variables such as; job position implies either senior or junior categories and length of service has four categories as indicated earlier, but this was later categorized into two major types; employee with less than ten year of service was tagged "short service employee", while those with ten years and above were regarded as "long service employee".

\section{Section B: General Perception of Downsizing Scale}

This section sought to determine respondents' general perception of downsizing exercises in their respective establishments. The instrument was close-ended questionnaire using the combination of items adapted from Multi -Item Perception of Downsizing Scales developed by Sronce and McKinley (2006), and Perceived Fairness of Downsizing Exercise Scale developed by Brockner et al (1992).

Section C: Tennessee Self-concept Scale (TSCS)

The study also adapted the Tennessee Self-Concept Scale (TSCS) developed by Fitts and Warren (1996). The scale is a widely used self-report measure consisting of six self- concept scales (physical, moral, personal, family, social and academic/ work) that yield a total summary score for total self-concept. Respondents were asked to indicate how true each statement is about them using a five-point scale ranging from "completely false" to "completely true". Negatively worded items are reverse scored.

Section D: Organizational Commitment Questionnaire (OCQ) 
The survey instrument used to measure employee's commitment to work in this study is eighteen-item scale, which measures the three components of commitment, as proposed by Meyer and Allen (1991). These components include, affective, normative and continuance commitment. A revised version of the instrument by Meyer, Allen and Smith (1993) and Meyer and Allen (1997), only contained 18-items of 6 items on each of the three components.

\subsection{Procedure}

The data were collected in batches. The first batch of data were collected within the last seven days in the month of March, 2009 in one of the establishments i.e. Nigerian Port Authority (NPA) in Lagos, while the remaining batch of data were collected between April and early May 2009 in the five establishments, which are located in the Federal capital Territory, Abuja. In Nigerian Ports Authority's, Marina Headquarters, Tincan Island and Apapa Wharf, a total of 350 questionnaires' were distributed out of which only 292 were returned and 284 were duly completed. A total of 500 questionnaires were distributed in five different establishments in Abuja. The order of the distributions is as follows: Ministry of Finance- 125, Ministry of Mines and Steels Development- 100, Federal Character Commission- 75, National Orientation Agency- 100, National Council for Museums and Monuments-100. On the whole, a total number of 850 questionnaires were distributed out of which 702 were returned. Out of these, 604 were found to be duly completed and useful for analysis. 148 were not returned, while 98 were either not filled or not completed and thus rejected. Altogether, a response rate of $71 \%$ was recorded.

\section{Results Analysis}

\subsection{Demographic Analysis}

Six hundred and four (604) employees in the six federal government establishments responded to the research instrument, $(M=37.6$, S.D =7.77). They were mostly between $31-50$ years of age.

\subsection{Hypothesis Testing}

The hypothesis, which, states that psychosocial factors (self concept and length of service) will significantly mediate the relationship between employees' perception of downsizing and their commitment to work was tested by series of multiple regression. The result is presented in Table below

\section{$<$ Table 1 about here $>$}

Model 1 as presented in Table above shows that independent variable (perception of downsizing exercise) significantly related to the psychosocial factors (self concepts and length of service). A detailed assessment of the analysis in Model 1 further reveals that perception of downsizing exercise is significantly related to self-concept $(\beta=0.25 ; \mathrm{t}=6.24 ; \mathrm{p}<$ $0.01)$. Likewise perception of downsizing exercise is significantly related to length of service $(\beta=0.11 ; t=2.61 ; p<0.05)$. The result in Model 2 shows that perception of downsizing exercise (independent variable) has a significant influence on employees' commitment to work (dependent variable) $\{\beta=0.17 ; \mathrm{t}=4.14 ; \mathrm{P}<0.01\}$. The result in model 2 has, therefore, shown that perception of downsizing, while controlling for psychosocial variables can predict employees' commitment to work.

In addition, Model 3 on the table above shows the test of mediation among variables of interest by introducing each of the psychosocial factors as mediator between perception of downsizing and employees' commitment to work. The results as presented in Model 3 on the table, reveal that self- concept significantly mediated the relationship between perception of downsizing and employees' commitment to work $(\beta=0.36 ; \mathrm{t}=9.24 ; \mathrm{p}<0.01)$. When both self-concept (mediator) and perception of downsizing (independent variable) were introduced on employees' commitment to work (dependent variable), the joint percentage influence was $39 \%(\mathrm{R}=0.39 ; \mathrm{F}(2 ; 601)=52.44 ; \mathrm{p}<0.01)$. Independently, self-concept contributed $36 \%$. This is higher than beta value obtained when mediating variables were held constant in Model 2. This result, therefore, shows that the relationship between employees' perception of downsizing and their commitment to work was mediated by self-concept. This implies that employees' self concept significantly mediated the Federal workers perception of downsizing exercise and their subsequent reaction in form of commitment to work.

The results as presented in Model 3 also show that length of service significantly mediated the relationship between perception of downsizing and employees' commitment to work $(\beta=0.14 ; \mathrm{t}=3.56 ; \mathrm{p}<0.01)$. When both length of service (mediator) and perception of downsizing (independent variable) were introduced on employees' commitment to work (dependent variable), the joint percentage influence was $22 \%(\mathrm{R}=0.22 ; \mathrm{F}(2 ; 601)=15.08 ; \mathrm{p}<0.01)$. Independently, length of service contributed $14 \%$. This is greater than beta value obtained when mediating variables were held constant in Model 2. This result, therefore, shows that the relationship between employees' perception of downsizing and their commitment to work was significantly mediated by length of service. This implies that employees' length of service significantly mediated the Federal Government workers perception of downsizing exercise and their subsequent reaction 
in terms of commitment to work.

\section{Discussion}

The primary focus of the present study is to contribute to the knowledge in the area of understanding the relationship between organizational downsizing/retrenchment and employees' commitment to work in general. Specifically, the study aims to contribute to the knowledge in the area of determining the psychosocial factors that could mediate employees' perception of downsizing and commitment to work among workers in the public institutions in Nigeria. This is because the empirical investigations have shown that even though, employees' interpretation of downsizing exercise may influence their subsequent work commitment, but it may not be sufficient to predict the direction of commitment. This study therefore, developed a model which explained the mediating role of the psychosocial factors in the relationship between perception of organizational downsizing and employees' commitment to work. The conceptual framework also proposed that psychosocial factors can act as a mediator in this relationship.

The result of analysis provides significant support for the hypothesized relationship among all the variables of interest in this study. With regard to the hypotheses formulated to guide this study; the conceptual model in this hypothesis predicted that the relationship between perception of downsizing exercise (independent variable) and employees' commitment to work (dependent variable) will be significantly mediated by psychosocial factors (self-concept and length of service). This hypothesis was supported and will be discussed from three different perspectives. That is, the relationship between perception of downsizing exercise (independent variable) and employees' commitment to work (dependent variable); the relationship between perception of downsizing exercise (independent variable) and psychosocial factors (mediating variables) and; and the mediating role of psychosocial factors in relationship between perception of downsizing and employees' commitment to work.

The result in model one of hypothesis tested revealed that perception of downsizing exercise significantly related to each of the psychosocial factor. In other words, the Federal civil servants' perception of the recent government's downsizing exercise is significantly related to their self-concept and length of service. This invariably means that perception of downsizing exercise is a multifaceted determined concept. Thus a general perception of the recent government's downsizing exercise among the federal government's employees should include the following psychosocial variables (self-concept and length of service). The major reason for this may not be unconnected with the role played by individual personality differences and experience in terms of biological make-up, orientations and social development. The finding also finds support in the study of Kirton and Mulligan (1973), which compared the extraversion- byneuroticism grouping and found that personality variables interacted with employees' attitude towards changes in managerial practices in general.

The model two of this hypothesis, while controlling for mediating variables reveals a moderate but significant relationship between perception of downsizing and employees' commitment to work. In other words, the federal civil servants' perception of the recent government's downsizing exercise had moderate, but significant effect on their commitment to the government job, especially when other psychosocial factors were held constant. This means that perception of downsizing (independent variable) has minimal influence on the level of work commitment among employees of the federal government. The reason for this finding could be that employees in the public institutions of Nigeria are discouraged with the implementation of downsizing by the Federal Government. This development would definitely dampen their morale and consequently affect commitment negatively. This conclusion is in agreement with the findings of Bennett and Durkin (2000) who found that downsizing has significant effect on the organizational commitment. Sharing this view, Macky (2005) also reports a significant decrease in organizational commitment after downsizing began. Other scholars who have demonstrated the relationship between downsizing and organizational commitment include; St. Amour (2000), Worrall, Cooper, and Cambell-Jamson (2000), Appelbaum, Delage, Labib and Gault (1997).

Model three of hypothesis tested shows the result of the mediating role of the psychosocial variables (self-concept and length of service) between the perception of downsizing (independent variable) and employee's commitment to work (dependent variable). The results indicate that the hypothesis was largely confirmed, that is, psychosocial factors (self-concept and length of service) mediated significantly, the relationship between employees' perception of downsizing and their commitment to work. This result therefore shows that the relationship between the Federal civil servants perception of downsizing and their subsequent reaction in term of commitment to work was mediated by self-concept. The result corroborated the finding of Kirton and Mulligan (1973) who also reported positive and significant relationship between employees' personality and lowest level of discontent with the organization and with superiors. Other scholars who have demonstrated the importance of personality factor on work behaviour include; Lee \& Peccei, 2006; Armstrong-Stassen 2001; Judge \& Hurst, 2007; Best, Stapleton \& Downney, 2005; Bono \& Colbert, 2005; 
Salvaggio, Schneider, Nishii, Mayer, Ramesh \& Lyon, 2007.

Similarly, length of service was also found to mediate the relationship between perception of downsizing and employees' commitment to work. The result finds support in the works of O'Reilly et al, (1998) and Cohen (1993). This result therefore shows that the relationship between the Federal civil servants perception of downsizing and their subsequent reaction in term of commitment to work was significantly mediated by length of service. Meanwhile, the conclusion drawn from the conceptual model, which explained this hypothesis, is that psychosocial factors (self-concept and length of service) have propensity to influence the way employees of the federal government interpreted the last downsizing exercise, and subsequently mediate the relationship between their perception and their responses in terms of employees' commitment to work. A possible reason for this finding could be found in the explanations of Mishra and Spreitzer (1998). They grouped downsizing survivors' behaviour into two broad categories; constructive such as feeling and expression of commitment, hope and willingness to solve problems and to take initiatives, while on the other hand, destructive categories which may include feelings and expression of fear, anger, withdrawal and retaliation. Ordinarily, the federal civil servants would have responded in a destructive ways like what many studies in this area suggested, but they resolved to act contrarily as reflected in their expression of commitment to the government's job. The major factor responsible for this development could be traced to their psychosocial variables (self-concept and length of service). That is, the decision of the employees in the federal civil service to be committed to their job, despite the effect of downsizing, is based on the fact that majority of the employees have positive self-concept and are highly experienced. This conclusion is buttressed by the moderate influence of perception of downsizing on employees' work commitment as expressed by the federal civil servants in model two of the hypothesis tested.

\section{References}

Adegoroye, G. (2006); 'Public service reform for Sustainable Development: The Nigerian Experience' Keynote Address at The Commonwealth Advanced Seminar, Wellington New Zealand, 20th Feb. - $3^{\text {rd }}$ March, 2006.

Ajila, C.O. \& Okeowo, O. (2004) 'Influence of Age, Gender and Education on Employees' Commitment to Work', Pakistan Management Review, Vol. XLI No 2: 25 - 35.

Anderson-Connolly, R. \& Greenberg, E.S. (2000); 'Surviving Layoffs: The Effect on Organizational Commitment and Job Performance' Journal of Work and Occupations, 27, (1) $7-31$.

Appelbaum, S.H., Delage,C., Labib,N. \& gault, G. (1997); 'The survivors' Syndrome Aftermath of Downsizing' Career Development International, 2: 278 - 286.

Armstrong-Stassen, M. (2001) 'Reactions of Older Employees to Organizational Downsizing: The Role of Gender, Job Level, and Time’ The Journal of Gerontology Series B: Psychological Sciences and Social Sciences 56 (4) 234-243. doi:10.1093/geronb/56.4.p234, http://dx.doi.org/10.1093/geronb/56.4.p234

Ayinde, A.T. (2005); ' Perception of Performance Appraisal Process among Civil Servants in Osun State' Unpublished M.Sc Thesis, Obafemi Awolowo University, Ile-Ife, Osun State.

Bennett, H. \& Durkin, M. (2000); 'The Effects of Organizational Change on Employee Psychological Attachment: An $\begin{array}{lllll}\text { Exploratory Study'. Journal of } & \text { Managerial }\end{array}$ http://dx.doi.org/10.1108/02683940010310328

Best, R. G., Stapleton, L. M., \& Downey, R. G. (2005) 'Core self-evaluations and job burnout: The test of alternative models'. Journal of Occupational Health Psychology, 10, 441-451. http://dx.doi.org/ 10.1037/1076-8998.10.4.441

Bono, J. E., \& Colbert, A. E. (2005) 'Understanding responses to multi-source feedback: The role of core self-evaluations'. Personnel Psychology, 58, 171-203. http://dx.doi.org/10.1111/j.1744-6570.2005.00633.x

Bragg, T. (2002), "Improve employee commitment", Industrial Management, pp.18-21.

Brockner, J., \& Wiesenfeld, B.M. (1996); ‘An Integrative Framework for Explaining Reactions to Decisions: Interactive Effects of Outcomes and Procedures'. Psychology Bulletin, 120(2) 189-208. doi:10.1037/10033-2909.120.2.189, http://dx.doi.org/10.1037/10033-2909.120.2.189

Brockner, J., Davey, J. \& Carter, C. (1985); 'Layoffs, Self Esteem and Survivor Guilt: Motivational Affective and Attitudinal Consequences Organizational Behavior and Human Decision Processes, 36(2) 113-127. http://dx.doi.org/10.1016/0749-5978(85)90014-7 
Brockner, J., Grover, S., Reed, T., Dewitt, R.L., \& O'Malley, M. (1987); 'Survivors' Reactions to Layoffs: We Get by With a Little Help for Our Friends'. Administrative Science Quarterly, 32, 526-541. http://dx.doi.org/10.2307/2392882

Brockner, J., Tyler, T.R., \& Cooper-Schneider, R. (1992); 'The influence of Prior Commitment to an institution on reactions to perceived unfairness: The Higher they are, the harder the fall' Administrative science Quarterly, 37,241-261. http://dx.doi.org/10.2393223

Brockner, J., Wiesenfeld, B.M., \& Martin, C.L. (1995); 'Decision Frame, Procedural Justice, and Survivors Reactions to Job Layoffs'. Organizational Behavior and Human Decision Processes, 63(1) 59-68. http://dx.doi.org/10.1006/obhd.1995.1061

Bureau of Public Service Reforms, (BPSR) (2006); 'Nigeria Public Service Reform: General Guidelines for the Reform of Ministries, departments and Agencies (MDAs) in Federal Civil Service’. Abuja: Asokoro.

Camp, S.D. \& Steiger, T.L. (1995) 'Gender and Racial Difference in Perception of Career Opportunities and the Work Environment in a Traditionally White Male Occupation' in A.J. Niky (eds.) Issues in Criminal Justice: Shaping Tomorrow System. New York: McGraw-Hill.

Cohen, A. (1993); 'Organizational Commitment and Turnover: A Meta-Analysis'. Academy of Management Journal, 36, 1140-1157. http//dx.doi.org/10.2307/256650

Dordevic, B. (2004); 'Employee Commitment in Times of Radical Organizational Changes'. Economic and Organization, 2: 111-117.

Evered, R. D. (1977) ‘Organizational Activism and its Relation to 'Reality’ and Mental Imagery. Human Relations. 30, $311--334$.

Federal Character Commission (2007) 'Twelfth Annual Report' Plot 64, First Avenue, off Shehu Shagari Way, Abuja

Federal Character Commission (2005) 'Tenth Annual Report' Plot 64, First Avenue, off Shehu Shagari Way, Abuja

Fitts, W. H., \& Warren, W. L. (1996). Tennessee Self-Concept Scale: Manual. United States: Western Psychological Services.

Greenhalgh, L \& Rosengbatt, Z. (1984). Job insecurity: Toward a conceptual clarity. Academy of Management Review, 9: 438-448. http://dx.doi.org/10.5465/AMR. 1984.4279673

Griffin, R. W. \& Bateman, T. S. (1986); 'Job Satisfaction and Organizational Commitment' in C.L. Cooper and I. Robertson (Eds). International Review of Industrial and Organizational Psychology, (2), New York: Wiley.

Guiniven, J. (2001); 'The lessons of survivor literature in communicating decisions to downsize'. Journal of Business and Technical Communication, 15(1), 53-71. http://dx.doi.org/ doi:10.1177/105065190101500103

Guttman, J. (1973) 'Self-concepts and television viewing among women’ Public Opinion Quarterly, 37(3) 388 -397. http://dx.doi.org/10.1086/268100

Heider, F. (1958). The Psychology of Interpersonal Relations. New York: Wiley. Doi:10.1037/10628-001, http://dx.doi.org/10.1037/10628-001

Herscovitch, L. \& Meyer, J.P. (2002) Commitment to Organizational Change: Extension of a three-component model. Journal of Applied Psychology, 87, 474 - 487. http://dx/doi/org/10.1037//0021-9010.87.3.474

Judge, T. A., \& Hurst, C. (2007). 'The benefits and possible costs of positive core self-evaluations: A review and agenda for future research'. In D. Nelson \& C. L. Cooper (Eds.), Positive organizational behavior (159-174). London, UK: Sage Publications

Kaye, B. L. (1998) 'The Kept on Workforce’ Training and development, 52, 32 - 36.

Kirton, M.J. \& Mulligan, G. (1973) 'Correlate of Managers' Attitudes toward Change' Journal of Applied Psychology, 58, 101 - 107. http://dx.doi.org/10.1037/hoo35425

Lee, J. \& Peccei, L. (2006) Perceived organizational support and affective commitment: the mediating role of organization-based self-esteem in the context of job insecurity. Journal of Organizational behaviour, 28(6) 661 685.

Lloyd and .V \& Weissman, W. (2001); 'Against the Workers; How IMF and World Bank Policies Undermine Labour Power and Rights'. The Multinational Monitor, 22:9, September. 
Macky, K. (2005); 'The negative impacts of downsizing'. Messy Newsletter, Messy University, New Zealand. (Online) http//aboutmassey.ac.nz/. ( March 2 2007).

Marskeller, R.A. \& Slocum, J.W.(1972) 'Prediction of Psychological need Satisfaction' Training and Development Journal. 26, 50 - 59 .

Meyer, J., \& Allen, N. (1997). Commitment in the workplace. Thousand Oaks, CA: SAGE Publications.

Meyer, J.P. \& Allen, N.J.(1991); 'A three-component conceptualization of organizational Commitment'. Human Resource Management Review, 1, 61-89. http://dx.doi.org/10.1016/1053-4822(91)90011-Z

Meyer, John P., Allen, Natalie J. and Smith, Catherine A., (1993); 'Commitment to Organizations and Occupations: Extension and Test of a Three-Component Conceptualization. Journal of Applied Psychology, 78(4), 538-551. http://dx.doi.org/10.10.1037//0021-9010.78.4538

Mishra, A. K., \& Spreitzer, G. M. (1998)‘ Explaining how Survivors Respond to Downsizing: The Roles of Trust, Empowerment, Justice, and Work Redesign'. Academy of Management Review, 23(3) 567-588. http://doi.org/10.5465/AMR.1998.926627

Mowday, R.T., Porter, L.W. \& Steers, R.M. (1982); 'Employee-organization linkages: The psychology of commitment, absenteeism and turnover's'. Academic Press, New York. NY

O'Reilly, C. \& Chatman, J. (1986); 'Organizational Commitment and Psychological Attachment: the effects of Compliance, Identification, and Internalization on Prosocial Behaviour' Journal of Applied Psychology, 71,492-499. http://dx.doi.org/10.1037//0021-9010.71.3.492

Ritzer, G. \& Trice, H.M. (1969) An occupational Conflict. Ithaca. Cornell University, Trice. http://dx.doi.org/ $10.2307 / 253.4 .537$

Robinson, S.L., Kraatz, M.S., \& Rousseau, D.M. (1994); 'Changing obligations and the psychological contract: A longitudinal study’. Academy of Management, Journal, 37(1), 137-152. http://dx.doi.org/10.2307/256773

Salvaggio, A. N., Schneider, B., Nishii, L. H., Mayer, D. M., Ramesh, A., \& Lyon, J. S. (2007). 'Manager personality, manager service quality orientation, and service climate: Test of a model'. Journal of Applied Psychology, 92, 1741-1750. http://dx.doi.org/10.1037/0021-9010.92.6.1741

Socialist Democracy (2002) 'Three Years of Civilian Rule: Which Way for the Masses' Retrieved May 82008 from www. http:// socialist world.net/eng/2002/05/13 Nigeria. htlm.

Spreitzer, G. M. \& Mishra, A. K. (2002); 'To stay or to go: Voluntary Survivor Turnovers Following an Organizational Downsizing,. Journal of Organizational Behavior, (23) 707-729. http://dx.doi.org/10.1002/job.166

St. Amour, D., Worral, L., Cooper, c. L. \& Cambell, F. K. (2000); 'Surviving Redundancy: The perception of U K Managers'. Journal of Managerial Psychology, 15 (5), 119 -124.

Strauser, D. R. (1995). Application of self-efficacy theory in rehabilitation counseling. Journal of Rehabilitation, 61 (1), 711.

Strauser, D. R., Waldrop, D., Hamsley, J., \& Jenkins, W. (1998). The role of self-efficacy and locus of control in job readiness training programs. Work: A Journal of Prevention, Assessment \& Rehabilitation, 10, 243-249.

Stronce, R. \& McKinley, W. (2006); 'Perceptions of Organizational Downsizing' Journal of Leadership and Organizational Studies. Summer.

Turnley, W.H., \& Feldman, D.C. (1998); 'The psychological contract Violations during Restructuring'. Human Relations Management, 37(1) 71-84. http://dx.doi.org/10.1002/(sici)1099-050x(199821)37:ic71:AID-HRM7>3.3co:2-3

Wanberg, C.R., Bunce, L.W., \& Gavin, M.B. (1999). Perceived fairness of layoffs among individuals who have been laid off: a longitudinal study. Personnel Psychology, 5(2), 59-84. http://dx.doi.org/ doi:10.1111/j.1744-6570.1999.tbo1813.x

Weiner, B. (1986). An attributional theory of motivation and emotion. New York: Springer-Verlag.

Weiner, B. (1980). Human Motivation New York: Holt, Rinehart and Winston.

Weiner, B. (1974). (Ed.). Achievement Motivation and Attribution Theory. New Jersey: General Learning Press.

Worrall, L., Cooper, c. L. \& Cambell, F. K. (2000); 'Surviving Redundancy: The perception of U K Managers'. Journal of Managerial Psychology, 15 (5), 119 -124. http://dx.doi.org/10.1108/02683940010337202 
Table 1. Summary of the Multiple Regression Analysis showing the Mediating Role of Psychosocial Factors on the Relationship between Perception of Downsizing and Employees' Commitment to work

\begin{tabular}{|l|lr|c|l|}
\hline MODEL & PATHS & & BETA & $\mathrm{R}^{2}$ \\
\hline 1. & PDE & SC & $0.25^{* *}$ & 0.06 \\
\hline & PDE & LS & $0.11^{*}$ & 0.01 \\
\hline 2. & PDE & ECW & $0.17^{* *}$ & 0.03 \\
\hline 3. & PDE \& SC & ECW & $0.36^{* *}$ & 0.39 \\
\hline & PDE \& LS & $0.14^{* *}$ & 0.22 \\
\hline
\end{tabular}

${ }^{*} \mathrm{p}<0.05 ;{ }^{*} \mathrm{p}<0.01$

Keys:

PDE: Perception of Downsizing Exercise

SC: Self-Concept

LS: Length of Service

ECW: Employees' Commitment to Work

(Independent Variable)

(Dependent Variable)

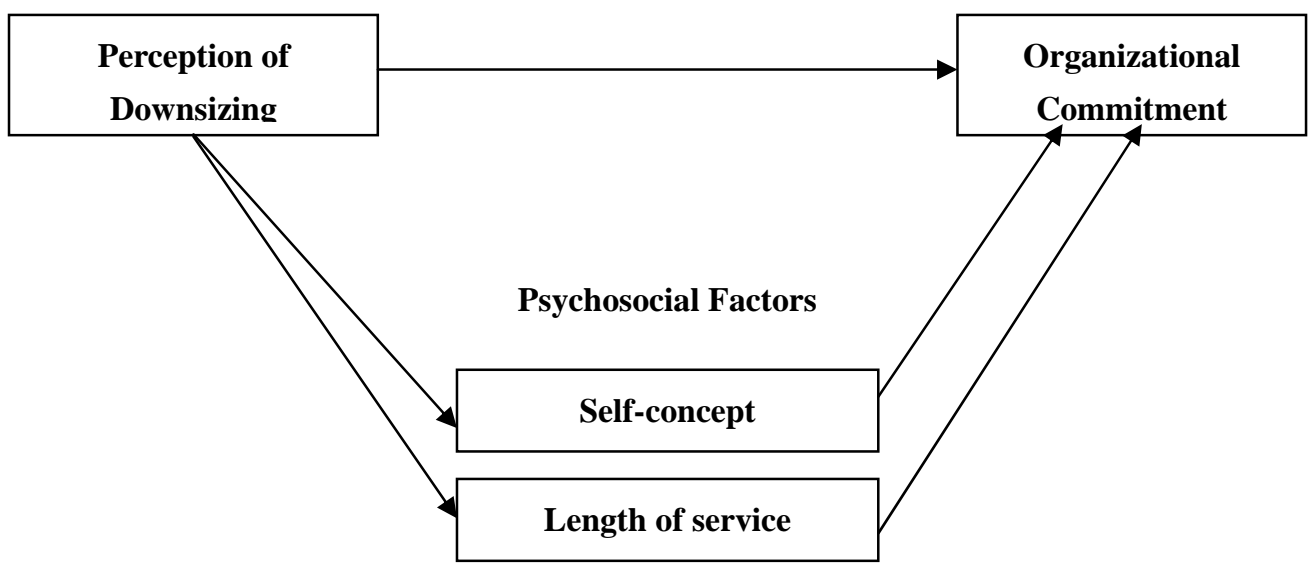

(Mediating Variables)

Figure 1. Conceptual Model of the Relationship between Downsizing and Employees' Commitment to Work and the Mediating Role of Psychosocial Factors on the Relationship 